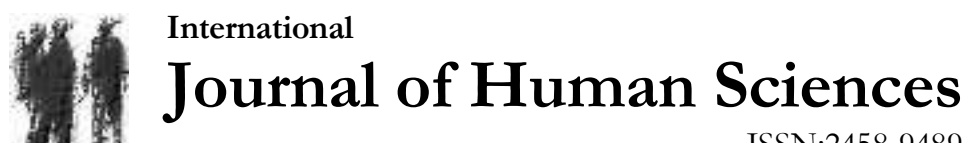 \\ ISSN:2458-9489
}

Volume 17 Issue 4 Year: 2020

\section{Human security in developing regions: Critical perspectives of health security in Nigeria}

\author{
Mahmudat Olawunmi Muhibbu-Din ${ }^{1}$
}

\begin{abstract}
Rising epidemic of communicable and non-communicable diseases, exacerbate the Nigeria health indicators. Low budgetary allocation and lack of policy prioritisation further weakened the health sector adding to spate of preventable and avoidable morbidity and mortality rate in the country. This study explores health insecurity as vital core of human security in Nigeria; securitization of health for policy priority; and the range of health challenges that pose threats to human wellbeing. Explorative method and comparative analysis are adopted to investigate the 'existential threat' that health insecurity pose to human lives and livelihood. The paper suggests prioritizing health issues and improving access and quality of services; assuring its availability and accessibility to all Nigerians.
\end{abstract}

Keywords: Epidemic, communicable diseases, non-communicable diseases, health, human.

\section{Introduction}

Human security is an evolving concept in the discourse of security. It transcends the traditional concept of state security and gives individual security primacy over territorial security (UNDP HDR 1994, CHS 2003). The post-cold war era and emerging security threats revitalize the urgency to refocus security on human well-being and welfare. Broadening and deepening security analysis from traditional military threats to encompass non-military threats that afflict human wellbeing in their daily lives from diseases, hunger, discrimination, poverty, trafficking in arms, drugs and humans, gained prominence as inter-state military conflict wane.

Human security was reinvigorated in the idea of "Responsibility to Protect" (R2P) championed by Canada as well as the "Responsibility for Development" (R4D) by Japan (Tadjbakhsh and Chenoy 2007), under the auspices of the United Nations Commission on Human Security (CHS 2003). However, the human security agenda elicit criticism from developing regions over the fear that the initiative will trample on national sovereignty of nations (Tadjbakhsh 2005).

Human security, embraced in academic and policy circles, offers opportunity for new analysis and insight. Propagated in the UNDP 1994 Human Development Report (HDR), human security

\footnotetext{
1 Ph.D. in Political Science and a Lecturer in the Department of Political Science, University of Maiduguri, ajoocurrent@yahoo.com (iD) Orcid ID: 0000-0001-9718-6996
} 
Muhibbu-Din, M. O. (2020). Human security in developing regions: Critical perspectives of health security in Nigeria. Journal of Human Sciences, 17(4), 1054-1068. doi:10.14687/jhs.v17i4.5719

has seven different dimensions- and health is stated as one of the key component of human security and central element of human development.

Increasing global interdependence and movement across the borders contribute to transnational transmission of diseases. Thus, outbreak of a disease constitutes security threat that can lead to possible transmission of diseases across borders. This may exert heavy toll on economies, and result in preventable and avoidable morbidity and mortality. Health security as a dimension of human security straddles the twin aspect of human security as freedom from want and freedom from fear. Freedom from fear from epidemic or pandemic that can be curtailed to prevent or ameliorate morbidity and mortality, and associated social, economic impacts on lives and livelihood. Freedom from want point to poverty, deprivation-induced diseases that contribute to low health index for developing countries like Nigeria.

Thus, the paper examines the concept of health security, the importance of securitizing health, health security in developing regions, and health security challenges in Nigeria, and conclusion.

\section{Health Security: Conceptual Analysis}

The literature on health security lack consensus on its definition. Nonetheless, emphasis shift in meaning from bioterrorism, to trans-border spread of diseases, escalating spending on health care and health insurance in advanced nations, HIV/AIDs and Infectious Diseases (IDs) rampant in developing nations (Aldis 2008:372). Conceptual and empirical analysis of health security moves from sub-state to global level. Thus, health security can be define as public good with implications for international relations (Callebero-Anthony 2006a). Health security has been defined in terms of foreign policy of powerful nations, which inject high power politics into global health discourse (Feldbaum, Patel, Sondrorp and Lee 2006, Ingram 2005, Kelle 2007). At the local level, as deplorable health services as health insecurity heightened in conflict-afflicted zone (Iqbal 2006, Morikowa 2008, and Soyinbo 2005). Few literature, investigate health security at local level in non-conflict regions (Callebero-Anthony 2006b, Chen 2004). Aldis (2008) is critical of literature that limits health security merely to global health security excluding important local health concerns such as maternal mortality rate, infant mortality rate, communicable diseases (CDs) and non-communicable diseases (NCDs) that are essential to human security, common in developing regions.

According to Aldis (2008:369-375) health security entails international response to stem trans-border spread of communicable diseases. Thus, the 2007 World Health Report (WHR) paid attention to global health threat, which emphasizes compliance with revised International Health Regimes (IHR). As much as this is important and provides precision on global health security, far less attention have been paid to important health concerns such as maternal and infant mortality and malnutrition prevalent in developing countries.

Divergences are common in the literature on the subject matter of health and human security. However, recurring ideas in the literature include: protection against hunger, poverty, disease or repression; protection against pandemic of CDs such as Severe Acute Respiratory Syndrome (SARS), as well as bioterrorism; providing medical and humanitarian reliefs in war afflicted states; partnership in primary health provision extending to military establishment, and foreign policy focus on trans-border spread of CDs (Aldis (2008: 371-372).

Nonetheless, developing countries have raised doubt on the integrity of global health initiatives and the preventive approach of IHR that allows for international collective action in support of weak states to curtail cross border spread of health threats. More importantly, linking foreign policy with national health problems of developed countries may distort global health and humanitarian concerns (Ingram 2005, Kelle 2007, Feldbaum, Patel, Sondrorp and Lee 2006, Aldis 2008). Developed nations may skew foreign policy and national security concerns as global health threats. This distorts global health priorities and limit global health spending to combating health 
Muhibbu-Din, M. O. (2020). Human security in developing regions: Critical perspectives of health security in Nigeria. Journal of Human Sciences, 17(4), 1054-1068. doi:10.14687/jhs.v17i4.5719

challenges of advanced countries. This not only undermine global health and humanitarian concerns, but can also cause theoretical misrepresentation in security study community.

In addition, the emergence of health security outside public health community and the variation in definition undermine its contribution and significance to public health. Nonetheless, health security logic involves primary health care integrating community roles, self-sufficiency, maternal care, and poverty reduction. However, health security restriction to protection against threat of bioterrorism, reduce the concept relevance and applicability to epidemiological and public health problems. Thus, for theoretical and practical relevance, health security need to respond to health threats causing unnecessary morbidity and mortality especially among the poor and vulnerable population (Aldis 2008:373).

Likewise, the feasibility of the prevailing primary health care and community health system to integrate the 'protection and empowerment' content ingrained in health security is doubtful. The protection component appears to de-emphasis active community role and selfreliance system. Health security success depends on its adequate integration into public health system relying on local and national capacity to respond to health threats. This implies the local capacity to protect and empower for effective response (Aldis 2008; Lancet 2008). Thus, the logic of human security framework is a bottom-up strategy that protects as well as empowers individuals and communities through strong health system (Lancet 2008:13).

Health threats ranging from infectious diseases, malnutrition and maternal and infant morbidity and mortality are preventable through poverty elimination and humanitarian intervention in conflicts. Poverty and wars pose considerable threat to health and human security. The CHS stresses the disease and poverty/conflict nexus. The responsibility for health security is expanding from state actors to non-state actors. Health security is integral to growth and development as ill health may precipitate economic crisis (UNCHS 2003:96). The rise of IDs can disrupt socio-economic, political, and military stability with potential consequences for human welfare and wellbeing.

From a positive conception of security, health security promotes a positive view of security, which is normative and addresses ontological state of well-being. Positive security conceives security in terms of desirable outcomes and what threats should be addressed and shield humans from; while negative security are pre-determined security measures (Roes 2008:778-80). According to McSweeney (1996), negative approach to health security emphasis "curative medicine without adequately balancing their significance to the overall quality of life". This undermines overall health care essential for wellbeing. A negative conception of health, limit policy alternatives, individual and or group capability over choice and activities (Roe 2008:780).

\section{Importance of Securitizing Health}

Security concerns have expanded beyond war and threat of war. Trans-national spread of diseases like AIDs, pose huge threat to international stability and peace. Cross border-spread of diseases can threaten economic and military capability of states. Nonetheless, securitization of health literature is yet to engage health security as fundamental area of focus. While primary health limits its focus on local health outcomes, international relations, on the other hand, debate whether the purview of health security should extend beyond bioterrorism (Maclean 2008).

Securitizing health has two implications for attracting needed resources to health, and will affect the spread of diseases especially HIV/AIDs and other IDs, transmitted across borders resulting from increasing global interconnectedness and interdependence (Maclean 2008). Securitizing health allows for policy prioritisation and increase revenue allocation. This raises health in the social sector just as defence and military matters are prioritise in the context of national security (Chen 2004:3).

Securitization of health like infectious diseases (IDs), integrated with other key strategies is a major approach to deal with health threat. Securitization framework and Global Public 
Muhibbu-Din, M. O. (2020). Human security in developing regions: Critical perspectives of health security in Nigeria. Journal of Human Sciences, 17(4), 1054-1068. doi:10.14687/jhs.v17i4.5719

Goods (GPGs) approach help deal with health and human security challenges, and are more effective and efficient in the prevention and control of IDs (Callabero-Anthony 2006a).

Prevention and control of IDs is a GPG that broaden the range of actors with appropriate policy intervention in responding to threats in ways that improve surveillance systems and curtail the spread of diseases through strong local health systems. Nevertheless, implicit in the GPG approach is the role of developed nations in the provision of health as a public good and the strengthening of local health capacity in weak countries where IDs are prevalent. Three core issues critical to advancing securitization of IDs include - regional synergy against disease outbreak, improving health system and health management strategy (CallaberoAnthony 2006a).

\section{Health Security in Developing Regions: Challenges and Prospects}

Health is one essential component of human security (UNCHS 2003:96). However, quality health care is not readily available to all. This constitutes a major threat to human security (Caballero-Anthony 2002:29). Health security relies on two-pronged approach to human securityprotection and empowerment proposed by the UNDP HDR 1994. Health security literature shows a strong link between economic development and health. Empowerment suggests economic wellbeing and impact health. War or conflict exerts huge toll on public infrastructure affecting negatively on health (Iqbal 2006). Poverty and war are threats to health security.

Health crisis in conflict and humanitarian emergencies, infectious diseases, poverty and inequity are drivers of health threats (Chen 2004:2). Health threats that affect human security are classified using these benchmarks - "scale, urgency, intensity, and externalities". Scale is health threats that affect significant portion of the population and prioritised. Health crisis in epidemic and war result in emergencies with ramification for human wellbeing (Chen 2004:3). Collaboration and synergy in information and knowledge sharing in international health governance in conjunction with human security is crucial. Health systems based on prevention, promotional and curative care, access to PHC and global health security are essential to achieving health for all.

Health threats that affect military security and disease outbreak can trigger major economic crisis such as SARS, less contested as human security threats. However, health problems that afflict most vulnerable population are not given policy and budgetary attention as human security threats. High maternal mortality ratio, malnutrition, Tuberculosis (TB), malaria and vaccine preventable diseases continue to be the major causes of morbidity and mortality among the poor (Chen 2004:5). Similarly, IDs account for four to five million death annually (Elbe 2013:335).

Chen raises the question, as the poor people get sick and die in great numbers, should the tragedies be considered humanitarian, developmental, or security? Many view these suffering and deaths as humanitarian, or even moral failure, but not security threat. Others view those health burdens as development failure. But, they are also huge human security failures. It makes very little difference to a mother if she loses her child to an infection that was preventable, or from a stray bullet during conflict. Why do we classify one type of loss as security-linked and the other not so? (Chen 2004:6).

Health security has positive relations to level of economic productivity, absenteeism at work and school. Common infectious diseases pose threat to health security. (Elbe 2013:335). SARS, avian flu (H5NI), and 'swine' flu (HINI) can pose threat to national security causing economic catastrophe and high mortality ratio. Ebola virus outbreak was devastating with grave consequences for health security in Sierra Leone and Liberia. Bioterrorism endanger national and human security, more prevalent in developed regions' fight against terrorism. 
Muhibbu-Din, M. O. (2020). Human security in developing regions: Critical perspectives of health security in Nigeria. Journal of Human Sciences, 17(4), 1054-1068. doi:10.14687/jhs.v17i4.5719

Caballero-Anthony (2002) investigates how access to PHC protects health security. Inadequate health care, poor health infrastructure, corruption, lack of political will undermine health care provision and quality of care. (Caballero-Anthony 2002:29-33). The absence of PHC impact on welfare and security of individuals. Caballero-Anthony concludes that inadequate and lack of health constitutes threat to health, and more devastating than the scourge of multi-drug resistance TB among others. Caballero-Anthony's three case studies (Cambodia, Philippines, and Indonesia) reveal that the health-seeking behaviour among the poor is non-treatment or selftreatment. Largely, financing health care is mostly out-of-pocket. Cambodia shows that traditional care is prioritised over consulting modern health facilities, and usually considered the last option (Caballero-Anthony 2002:31). In Philippine, six of every ten normal deaths resulted from inability to access any modern health care (Caballero-Anthony 2002:32). Indonesia reveals that, close to 80 percent of the mortality cases in poor areas were largely preventable.

Caballero-Anthony argues that human security approach to health includes, first, early prevention and, second, people-centeredness. It must be anticipatory in approach, policies and programmes are beneficiaries centred. This reinforces the idea that human security is preventive and not curative through early warning (Alkire 2003), and the empowerment of the people is integral to their health security (UNCHS 2003).

Knapp (2005) finds that health insecurity could pose severe threats to economic survival of household, with serious implications for national economic security. HBV epidemic caused colossal loss to large swaths of Sub-Sahara Africa. This diverted economic resources for development to fighting the disease outbreak that deteriorates economic capacity of poor nations. Loss of labour, and low economic productivity, resulting in decline in export, low income and dwindling foreign investment which further worsen the economy. Likewise, infection among military personnel poses considerable threat to national security. Health insecurity is linked to aggravating poverty level, social and economic instability. Knapp (2005) invigorates the perspectives that health security linked with national economic development (UNCHS 2003; Maclean 2008).

Health security have ramification for individual achievements. "A person's health is a central pillar not only of the quality of his life but his very survival". Health impact on individual capabilities to actualise their potentials, earn a living for themselves and their family as well as acquire skills for good living (Desai and Yamamoto 2004:5). Thus, health affects economic gains of nations. HIV infection rate of 10 percent reduce national income growth by one-third, while infection rate of 20 percent may result in 1 percent decline in GDP. HIV prevalence among economically active population will affect negatively on national income and GDP. WHO Commission on macroeconomic and health finding shows annual economic growth rate decline by 1.3 percent in countries where malaria is rampant (Benn, Omi and Rossert-Blavier 2004: 45). Meanwhile, SARs pose economic crisis estimated to cost the global economy $\$ 60$ billion. It triggered political instability and economic collapse in affected countries (Caballero-Anthony 2006b).

Global interconnectedness and spread of disease across borders has significant implications for economic and political security. Disease outbreak not only poses health threat but also can trigger economic collapse with grave consequences for the global economy (Thompson 2004:25, Callebero-Anthony (2006b). CDs including HIV/AIDs, TB and malaria are among the leading causes of morbidity and mortality prevalent in developing region with huge consequences for human security. Efficient primary health care is a crucial step in improving human security as health and global development are inextricably linked (Callebero-Anthony 2006b:29; 2002). Ill health affects quality of life, and intertwined with other forms of structural violence that severely degrade human security.

Economic disruption and rising poverty has severe implications for health. Poverty degrades children's capabilities and functioning. Findings show that rising income account for 20 percent fall in adult mortality and U5MR from 1960 to 1990. Though, knowledge utilization and educational improvement among women play important role; poverty, lack of basic education, 
Muhibbu-Din, M. O. (2020). Human security in developing regions: Critical perspectives of health security in Nigeria. Journal of Human Sciences, 17(4), 1054-1068. doi:10.14687/jhs.v17i4.5719

poor housing, social exclusion, unemployment, environmental hazards and poor earning all diminish opportunity and choices, and pose a health threat (Parmley 2000:1359-60).

Helle (et.al 2007), and Gwatkin (2000) consider health insecurity from inequity in health care. Gwatkin (2000:3-18) contribution to health security illustrates the poverty/inequality/equity in health policy. Policy orientation produces different health outcomes. Equity oriented health policy addresses the inequality engendered in health of the rich and poor and has the propensity to reduce death among the poor. The OECD 2015 economic target of halving the number of the poor stated in societal averages, cannot affect the health of the poor. This traditional way of expressing targets may possibly reduce death among people of high economic class cadre. Topdown strategy affect the middle class before it trickles down to the bottom of the economic class. A bottom-up approach, affect infant mortality ratio from among the poorest, where it is more rampant and move up the economic ladder. A bottom up approach in implementing health target is in tandem with human security.

Addressing health disparities and poverty is a major concern of public health policy in the $21^{\text {st }}$ century (Heller, Beaumont, Earle, Douglas and Jones 2007:155; Stronks and Mackenback 2005:346-7). Illness can put people at the risk of becoming poor and have consequences for societal wellbeing. Low-income group are predispose to preventable illness and avoidable death than higher income group. Thus, investment in community's health is both an economic requirement and humanitarian objective (Helle et.al 2007:163-168). Attrition of health work force is a major problem of developing countries resulting in increased workloads for health care workers and low productivity or poor service delivery, leading to further migration out of the system (Earle 2007).

\section{Health Security Challenges in Nigeria}

\section{Challenges of the Nigerian Health Sector}

Nigerian health system has three tiers namely: primary health care, secondary health care, and tertiary health care. That corresponds with the local, state, and federal health system. However, constraints at the state and local levels affect health delivery due to poor human resources and financing. Inadequate facilities and personnel constrain rural health care access (Tien et.al 2009:9). In post-independent Nigeria, various health plans suffer from poor implementation. Inadequate medical care presents crises of varying dimensions and intensities. Common causes of crises include high cost of medical services and insufficient health financing, poor health facilities, migration of qualified personnel, inadequate coverage of the existing health services, high prevalence of communicable diseases (CDs), declining health indices and lack of coordination among health services agencies (Daramola 1984, Makeri 2003, Ezeoke, Onwujekwe and Uzochukwu 2012, Amaghionyeodiwe 1999, 2009, FMoH 2006). Neglect of Primary Health Care (PHC) and its maldistribution constrained efficient health care services (Asuzu 2004, Massoud 2008). Explosive population growth and rising public expectations for increased access to improved quality health services aggravated the protracted decadence in social services delivery (FMoH 2006:5). Poor response mechanism to outbreak of epidemics and pandemics deteriorate the health care delivery system. The implementation of the Structural Adjustment Policies in the mid-1980s informed state roll back in social services provision including health care services. This worsened service delivery in the public health sectors and cost of provisioning in the private sector discourage usage.

Brain drain haemorrhages the system. Finding shows that close to 50 percent of locally trained health personnel emigrate aboard resulting in manpower loss for the health sector (Nwakioko, James, Switzer and Stern 2016), and 44 percent of U.S based Nigerian physicians are trained at home (Tankwanchi, Ozden, Vermund 2013). 
Muhibbu-Din, M. O. (2020). Human security in developing regions: Critical perspectives of health security in Nigeria. Journal of Human Sciences, 17(4), 1054-1068. doi:10.14687/jhs.v17i4.5719

\section{Health (In)Security}

Trajectory of diseases and infections shows that Nigeria record one of the lowest health index among nations. Emerging infectious diseases, including HIV/AIDS prevalence, TB and noncommunicable diseases (NCDs) attest to the appalling state of the Nigerian health system. Reemerging health problems associated with the HIV/AIDS pandemic and tuberculosis are prevalent. Malaria, HIV and diarrhoea are leading causes of death in Nigeria, and result in 25 percent death in adult population (NDHS 2008). Inadequate access to portable water supply and sanitation has severe health implications. One of every three Nigerians lack access to portable water. As a result, diarrhoeal remains a leading cause of death - second only to malaria, for children under 5 years of age (PSI website 2014). Recurring incidence of cholera in the country over the decades result in loss of lives and constitute threats to health security. In 2018 alone, 235 deaths in 17 states were recorded.

Nigeria shoulder 25 percent morbidity and mortality levels of malaria globally. It is a leading cause of mortality and responsible for over a quarter of under-five mortality, 30 percent, and 11 percent of infant and maternal mortality respectively (FMoH 2002, NDHS 2008). More so, malaria exert huge toll on communities and household to the tune of 132 billion naira per annum, diversifying economic resources from more productive activities to treatment, prevention and absenteeism lowering productivity and worsening poverty level and slowdown economic growth (NPHCDA 2007:13, NDHS 2008).

In a recent study on global Healthcare Access and Quality Index (HAQI) conducted among 195 countries, Nigeria ranked $140^{\text {th }}$ position far below many African countries. The HAQI based on 32 causes of death that are avoidable and preventable tracked countries progress from 19902015. These diseases include TB and other respiratory infections, vaccine preventable diseases such as measles, whopping cough, NCDs, maternal and new-born related health problems (The Guardian 2019).

According to the Nigerian Demographic and Health Survey, a quarter of children between 1-2 years were vaccinated. Measles vaccination coverage was 42 percent. Regional disparities exist in the level of coverage across the country. Nigeria is among the 47 priority countries with the highest measles mortality rate (National Centre for Diseases Control 2019).

Nigeria has the lowest vaccinations rate among African countries where Demographic Health Surveys (DHS) have been conducted since 1998. The 2003 NDHS enumerates the barriers to health. These include financial constraints (30 percent), lack of proximity to facility and transportation fees (24 percent each). One in ten women cannot secure their husbands' consent to visit facility.

Rising incidence of Non-Communicable Diseases (NCDs) combined with the existing prevalence of Communicable Diseases (CDs) deteriorating the health status of the country (FMoH 2010, NBS 2007). Causes of death by CDs and maternal, prenatal and nutrition conditions amount to 66 per cent in 2012; by NCDs is 24 per cent and injuries 10 percent in the same year (WDI 2015a).

NCDs and CDs constitute major causes of mortality and morbidity in Nigeria (FMoH 2010:28). In 2016, life expectancy at birth was 55/56 years (WHO, Nigeria 2019), still below the 67 years for Low and Middle-Income countries and 57 years for Sub-Sahara Africa (WDI 2015b). Recent study shows that life expectancy in Nigeria is improving. Life expectancy in Nigeria surpasses three Africa countries (South Africa, Niger and Cameroun), but below that of Ethiopia, Kenya and Rwanda (Vanguard 2017). Under-5 mortality per 1000 live births was 100 in 2017. In 2016, between 15 and 60 years' mortality ratio was $372 / 333$ per 1000. In 2014, per capita health expenditure amount to $\$ 217$. Aggregate health expenditure was 3.7 percent of GDP in 2014 (WHO, Nigeria 2019).

HIV/AIDS

Nigeria's has one of the most rapidly increasing rates of new HIV/AIDs burden in the world. Recent statistical data shows that over 3 million people have HIV/AIDS, but only 1.2 
Muhibbu-Din, M. O. (2020). Human security in developing regions: Critical perspectives of health security in Nigeria. Journal of Human Sciences, 17(4), 1054-1068. doi:10.14687/ihs.v17i4.5719

million have access to care. Adult population, age $15+$ of people living with HIV/AIDS is 2.9 million while children account for 220000 (USAID 2017). AIDs orphaned 1.8 million children. This poses serious socio-economic implications for their wellbeing and welfare (USAID 2017).

Cultural barriers, legal barriers and structural barriers hinder effective HIV response (AVERT 2019). Funding of HIV response is largely constrained by dependent on donors. Nigeria strategizes for funding through deduction of 1 percent from state monthly allocations from the FG to support HIV response. Also, private sector investment will increase from 2.1 percent in 2014 to 10 percent in 2018 (AVERT 2019)

\section{Tuberculosis}

On TB, Nigeria ranked fourth among countries with highest TB burden (FMoH 2010, NTBLCP 2010:10, and World Health Organisation 2017). The number of newly enrolled in HIV care was 232822 in 2017. In addition, 19533 (8.4 percent of newly enrolled HIV cases) have TB in Nigeria (WHO 2018a:75). New and relapsed TB cases in 2017 was 102387 and the percentage tested with rapid diagnostics was 41 percent. Rifampicin-resistance TB cases were 30 percent (WHO 2018a:77, 196).

In 2018, the national TB budget was $\$ 409$ million. Domestic sources account for 8 percent, 16 percent (international), and a whopping 76 percent of cases remained unfunded (WHO 2018:196). Efforts are on top gear to control and prevent TB as well as deal with multidrug resistant TB (MDR-TB), common with people infected with HIV. However, the control and prevention of TB is facing many challenges. These include the negative effects of HIV/AIDs and resurgence of drug-resistant TB. The HIV/AIDS pandemic fuel the burden of TB and poses excessive challenges for diagnosis and management. Nigeria is one of the ten countries that harbour 80 percent of people living with HIV and TB infection together (World Health Organisation 2017). Resurgence of MDR-TB is a major encumbrance to the feat achieved in TB control (NTBLCP 2010:4).

\section{Leprosy}

Leprosy disease is a public health challenge and record almost 5,000 cases per annum. Nationally, the leprosy incidence records a major decline in the number of cases due to continuous effort to eradicate the disease. However, leprosy remains prevalent at the local level. The main challenge facing people cured of leprosy but suffered disabilities is reintegration (NTBLCP 2010:4).

\section{Lassa Fever}

Lassa Fever (LF) fatal outbreak causes death in different part of the country. Nigeria records about 300, 000 new LF cases every year, and 5,000 mortality rate. Paucity of resources and investigation marred information gathering and knowledge about new cases (Viral Haemorrhagic Fever Consortium website 2016). Contact with rodent's urine and faeces are the primary means of transmission to humans. Other means of transmission is bodily fluids from infected persons. LF kills faster than HIV/AIDs as infected person die within two weeks of infection. There is no treatment for LF in human being except ribavirin. Ribavirin is only effective if applied within six days of infection. Lassa virus infection removes antibodies useful for treatment (Viral Haemorrhagic Fever Consortium website 2016).

In addition to previous years death toll, from January to April 2018, 413 patients were confirmed, possibly 9 Lassa fever cases, 114 deaths, and a total of 27 percent mortality rate. In the same period, seven states comprising Abia, Benue, Ebonyi, Edo, Kogi, Nasarawa and Ondo recorded 27 health workers' infection and eight death. This is the highest Lassa fever outbreak in Nigeria (WHO 2018b).

However, Lassa fever emergency response, management, and treatment centres are established in the affected states, collaboration with National Centre for Disease Control (NCDC), 
Muhibbu-Din, M. O. (2020). Human security in developing regions: Critical perspectives of health security in Nigeria. Journal of Human Sciences, 17(4), 1054-1068. doi:10.14687/ihs.v17i4.5719

WHO staff and Nigerian Epidemiology Field staff training, improved surveillance help to limit fatality and mortality. LF remains a dreaded health threat in Nigeria.

\section{Infant and Maternal Mortality}

In Nigeria, of every 1000 live births, 197 death occur. The National Health and Demographic Survey (NHDS 2008) report shows insignificant progress in maternal and infant health. Infant mortality was 75 per 1000 live birth, Under-5 Mortality decline from 199 to 157 deaths per 1000 and maternal mortality of 554 per 100000 are still very poor relative to the average for developing countries. Infant and child mortality is high, though decreasing, varied across regions. Infant mortality rate indicates that one child dies of every $7 / 8$ in the first twelve months, and U5MR is one of every six children (FMoH 2010:26).

Out of every 1000 live births, Nigeria still experience 46.6 percent Under5 mortality, far above the international rate of 38.4 percent and sub-Sahara rate at 40.7 percent. Nigeria rating is better than Niger, Mali and Chad (Vanguard 2017). The appalling health profile as evidenced in IMR and MMRs is connected to the low level of education. The federal government intensified maternal and childcare services, offering incentives to pregnant women, massive recruitments of mid-wives to improve maternal and childcare is yet to impact positively on improving maternal morbidity and mortality. (Cooke and Tahir 2013:8, Judd-Leonard 2012, Essen 2012).

Four major factors which predispose mother and infant to deaths include: "delays in seeking care when complications arise, reaching care when decisions are taken to seek care, accessing care on arrival at a health care facility; and in referring care from where it is initiated, to where it can be completed" (Ogundipe 2011). This emphasizes the importance of effective synergy among tiers of health care (Cooke and Tahir 2013:6).

Births delivered by skilled service providers dropped from 43 percent in 2003 to 39 percent in 2008. According to the NDHS 2008, the tendency for women to use health facilities during pregnancy is unconnected to residence, educational level, and socio-economic status. A primary school lever has 10 times more probability of using antenatal care, one times, and 4 times more likely to deliver in health facility than a woman without any education.

The FG's endorsement of global maternal health goal failed to translate to drastic reduction in maternal and infant mortality rate. Government must move beyond rhetoric to firm commitment through forging collaboration between government-civil society activities (Shiffman and Okonofua 2007).

\section{Fragile Primary Health Care}

Poor quality of services delivery shortage of resources, trained and qualified personnel, misdemeanour of health care providers undermines the health care services at the local level, resulting in low patronage and loss of confidence in the Primary Health Care (PHC) (Massoud 2008:20; Cooke and Tahir 2013:6). Asuzu (2004) argues that neglect of the PHC and secondary health care, and its mal-distribution will create "an inverted health care pyramid". This posed the danger of imminent health collapse. Prevalence of common diseases and maternal mortality at the local level indicates the quality of care at the local primary health care system (Massoud 2008:20; Cooke and Tahir 2013:6). Corruption and poor governance that characterised the Nigerian state also bedevilled the PHC. Local government lack of autonomy and financial dependence on State government, poor funding of PHC amount to inadequate supply of health products and services. Proliferation of health institutions without equipping them with basic medical supplies such as drugs, personnel, electricity, and water supply degrade the quality of health services (Amaghwnyeodwe 1999:389). 
Muhibbu-Din, M. O. (2020). Human security in developing regions: Critical perspectives of health security in Nigeria. Journal of Human Sciences, 17(4), 1054-1068. doi:10.14687/ihs.v17i4.5719

\section{Payment Out-of-Pocket}

The household health spending is over an average of 60 percent from 1998-2002 (WHO 2010:23). Despite increase in government health allocation from 1997 to 2001, settling out of pocket expenses remains high (Massoud 2008:21). Endemic corruption affects budgeted allocation to health. It is not clear whether budget allocations were actually spent on health services or end up in private pockets (Obiajulu 2007:5). Thus, rising health budgetary expenditure could not yield positive effect on health outcomes (Makeri 2008). Studies have shown that out of pocket expenses were 69.9 percent in 2004, and remains over 70 percent in 2014 (WHO Global Health Expenditure database). The growth in the proportion of care provided by private facilities increase cost of health care, resulting in diminished health care access (Obiajulu 2007, Ekeoke et.al 2012:55, Onwujekwe, Hanson and Uzochukwu 2012).

Out-of-Pocket (OOP) can exacerbate poverty for health seekers. Empirical investigation shows that OOP health financing push household below the poverty level and impact standard of living (Onoka, Onwujekwe, Hanson and Uzochukwu 2011:1334-41; Onwujekwe, Hanson, Uzochukwu, Ichoku, Ike and Onwughalu 2010):18-25). OOP may discourage the poor from utilizing health facilities (Olaniyan and Lawanson 2010:9, Duru and Nwagbos 2007).

On the other hand, only 4 percent of Nigerians are enrolled in the national health insurance scheme. Economic growth recorded over the years is yet to translate into universal health coverage. Ghana, Rwanda and Kenya rate higher in terms of number of population that have access to health care (Punch 2018).

Likewise, the National Health Bill that would address numerous challenges in the health sector is yet to be operational. It is expected that if the law come into reality most of the problems with the PHC will be resolved, the question of funding, maternal mortality will be given adequate attention and improve equity and accessibility of health care services in Nigeria.

\section{Conclusion}

In the aftermath of the cold war, alternative security thinking is bourgeoning as relevant focus for security analysis as inter-state military warfare decline and non-military threats continue to exert huge toll on human lives and wellbeing. Human security emerges in response to the security threats that the military state-centric approach failed to consider for policy and budgetary prioritisation, however integral to human wellbeing and welfare. Thus, human-centric approach to security becomes germane to security analysis especially on health.

Health is a 'vital core' of human security. Health insecurity has far-reaching consequences for human wellbeing. Health securitization will attract needed resources and policy attention. Communicable and non-communicable diseases are rising health security challenges and in most cases constitute 'existential threat' that state requires 'emergency measures' to curtail its spread to reduce morbidity and mortality.

Nigerian health sector is not immune from the numerous challenges confronting the country resulting from decades of neglect, poor policy implementation, and bad governance. Poor management and yawning gap between plans and achievements are other causes of failure. Infrastructure decay, obsolete, dysfunctional, and inadequate health services, personnel, medical supplies, are ubiquitous in the Nigerian health sector. Consequently, brain drain becomes the hallmark of the health sector aggravating the dearth of well-trained personnel. Deplorable decline in health indicators sub-regionally and regionally are dominant narratives. Major health threats particularly, non-communicable diseases pose grave danger for lack of needed equipment for treatment, and where available, they are inadequate and/ or dysfunctional. In addition, where available, the cost is usually prohibitive and unaffordable for the common person.

Similarly, vaccines preventable diseases and other avoidable death continue to exert huge toll on the lives and wellbeing of many Nigerians with severe implication for economic productivity and growth. Limited budgetary allocation exacerbates the problem in an atmosphere of inadequate 
Muhibbu-Din, M. O. (2020). Human security in developing regions: Critical perspectives of health security in Nigeria. Journal of Human Sciences, 17(4), 1054-1068. doi:10.14687/jhs.v17i4.5719

budget monitoring for accountability and transparency. Thus, medical tourism is ubiquitous among the political class and the few privileged class.

Improved health system is fundamental to ensuring the health security of Nigerians. Functional and effective health system at all levels and particularly the entry level of the health system, its linkage, and synergy with other levels of health care services provision is strategic to health security. Local government must be adequately equipped, across the country to provide functional primary health care at the first level of health care to prevent 'inverted health pyramid'. This is imperative not only in terms of its proximity to the communities but also, well-equipped health facilities to address numerous health problems that are leading causes of morbidity and mortality. This will go a long way to improve Nigeria's health indicators among developing countries and the world at large. Functional local health infrastructure and partnership among different tiers of health care providers as well as numerous stakeholders cannot be overemphasised in health security.

\section{References}

Aldis, W. (2008) 'Health Security as a Public Health Concept: A Critical Analysis' Health Policy and Planning, 23:369-375. https://doi.org/10.1093/heapol/czn030.

Alkire, S. (2003) A Conceptual Framework for Human Security Working Paper 2. Centre for Research on Inequality, Human Security and Ethnicity, CRISE Queen Elizabeth, University of Oxford, Available at http://www3.qeh.ox.ac.uk/pdf/crisewps/workingpaper2.pdf. Accessed on 12 March, 2010.

Amaghionyeodiwe, L. (1999) 'Fiscal Federalism, Health Care Spending and National Development: The Nigerian Experience' Selected Papers Presented at the 1999 NES Annual Conference on Fiscal Federalism and Nigeria's Economic Development, pp.379-404.

-- (2009) 'User Charges, Health Care Choice and Willingness to Pay for Public

Sector Health Services in Nigeria', In A. Adenikinju, D. Busari and S. Olofin (eds.) Applied Econometrics \& Macroeconometric Modelling in Nigeria, Ibadan: Ibadan University Press, pp.425452.

AVERT (2019) HIV and AIDS in Nigeria. Available at: https://www.avert.org/professionals/hivaround-world/sub-saharan-africa/nigeria. Accessed on 19/02/2019.

Benn, C., Omi, S. and Rossert-Blavier, H. (2004) Effective Regional and Global Responses to the Human Security Challenges of HIV/AIDS and Other Communicable Diseases in Asia. A Paper Presented in a Conference on The Human Security Challenges of HIV/AIDS and Other Communicable Diseases: Exploring Effective Regional and Global Responses, Tokyo: JCIE, pp. 44-50

Caballero-Anthony, M (2002) 'Overview of Health and Human Security Case Studies', In P. J. Noda (ed.) Health and Human Security: Moving from Concept to Action-Fourth Intellectual Dialogue on Building Asia's Tomorrow, Tokyo: Japan Centre for International Exchange, pp.21-44.

(2004) 'Revisioning Human Security in Southeast Asia', Asian Perspective, Vol.28, No. 3, pp.155-189. https://www.jstor.org/stable/42704471

(2006a) 'Human Security Approaches: Health as a Global Public Good'. A Paper Presented at a Conference on Cross-Border Cooperation in the Global Fight Against HIV/AIDs, Tuberculosis, and Malaria, Beijing.

- (2006b) 'Combating Infectious diseases in East Asia: Securitization and Global

Public Goods for Health and Human Security', Journal of International Affairs, vol. 59, no.2, p105-127. https://www.jstor.org/stable/24358429

Chen, L. (2004) 'Health as a Human Security for the $21^{\text {st }}$ Century'. Paper for Human Security Track III, Helsinki Process. http:// citeseerx.ist.psu.edu/viewdoc/summary?doi=10.1.1.176.681

Commission on Human Security (CHS) (2003) Human Security Now, Final Report of the Commission on Human Security, New York: United Nations Publishing: Available at http:// www.humansecurity-chs.org/finalreport/ (accessed 14 March 2010). 
Muhibbu-Din, M. O. (2020). Human security in developing regions: Critical perspectives of health security in Nigeria. Journal of Human Sciences, 17(4), 1054-1068. doi:10.14687/jhs.v17i4.5719

Cooke, Jennifer G. and Tahir, Farha (2013) Maternal Health in Nigeria. With Leadership Progress is Possible. A Report of the CSIS Global Health Policy Centre, Center for Strategic and International Studies (CSIS).

Daramola, T. (1984) Challenges of Providing Comprehensive Health Care for Nigerians. An Inaugural Lecture Delivered at the University of Ife on Tuesday, April 21, Inaugural Lecture Series 54.

Desai, V. N. and Yamamoto, T. (2004) Foreword Presented in a Conference on The Human Security Challenges of HIV/AIDS and Other Communicable Diseases: Exploring Effective Regional and Global Responses, Tokyo: JCIE, pp.5-6.

Duru E.J. and Nwagbos, C.I. (2007) The Problems and Prospect of Public Health Care Development in Nigeria's Local Government System, Global Journal of Social Science, Vol. 6, No.1, pp.51-56. http://dx.doi.org/10.4314/gjss.v6i1.22826

Earle, Sarah (2007) Promoting Public Health in a Global Context in C.E. Loyd, S. Handsley, J. Douglas, S. Earle and S. Spurr (eds.) Policy and Practice in Promoting Public Health, London: Sage Published in association with The Open University.

Esene, Isi (2012) "FG Promises Expectant Mothers N5000 Stipend", YNaija, July 232012 http://www.ynaija.com/fg-promises-expectant-mothers-n5000-stipend/. Accessed on $18^{\text {th }}$ March 2013.

Ezeoke O.P, Onwujekwe O.E, and Uzochukwu B.S (2012) Towards Universal Coverage:Examining Costs of Illness, Payment, and Coping Strategies to different Population Groups in Southeast Nigeria. The American Journal of Tropical Medicine and Hygiene, Jan; 86(1):52-7. doi: 10.4269/ajtmh.2012.11-0090

Federal Ministry of Health (2006) National Policy on Partnership for Health in Nigeria, Federal Secretariat, Abuja.

Federal Ministry of Health (2008) Review of Health Sector Reform Program, FGN.

Federal Ministry of Health Nigeria National Tuberculosis and Leprosy Control Programme (NTBLCP) Workers' Manual (2010) - Revised $5^{\text {th }}$ Edition.

Federal Ministry of Health (2010) National Strategic Health Development Plan (National Health Plan) 2010-2015, FGN.

Feldbaum, H., Patel, P., Sondorp, E. and Lee, K. (2006) 'Global Health and National Security: The Need for Critical Engagement' Medicine, Conflict and Survival, 22 (3): 192-198. DOI: $10.1080 / 13623690600772501$

Fiddler, D.P. (2003) Emerging Trends in International law concerning Infectious Disease Control, Emerging Infectious Disease, Vol. 9, No.3, pp.285-290. DOI:10.3201/eid0903.020336

Glasius, M. (2008) 'Human Security from Paradigm Shift to Operationalization: Job Description for a Human Security Worker', Security Dialogue, Volume 39, No. 1, pp.31-54. doi/10.1177/0967010607086822

Gwatkin, D. (2000) Health inequalities and the health of the poor: What do we know? What can we do? Bulletin of the World Health Organization, 78, 3-18.

Helle T, Beaumont K., Earle S. and Douglas J. and Jones L. (2007) 'Addressing Poverty and Health' in C.E. Loyd, S. Handsley, J. Douglas, S. Earle and S. Spurr (eds.) Policy and Practice in Promoting Public Health, London: Sage Published in association with The Open University

Ingram, A. (2005) 'The New Geopolitics of Diseases: Between Global Health and Global Security', Geopolitics, 10:522-545. https://doi.org/10.1080/14650040591003516.

Iqbal, Z. (2006) 'Health and Human Security: The Public Health Impact of Violent Conflict' International Studies Quarterly, 50,631-649. https://doi.org/10.1111/j.14682478.2006.00417.x.

Judd-Leonard, O. (2012) Nigeria: Expanded MSS Targets 3 Million Women, 19,000 Jobs, Daily Trust, 5 April 2012. 
Muhibbu-Din, M. O. (2020). Human security in developing regions: Critical perspectives of health security in Nigeria. Journal of Human Sciences, 17(4), 1054-1068. doi:10.14687/jhs.v17i4.5719

Kelle, A. (2007) 'Securitization of International Public Health: Implications for Global Health Governance and the Biological Weapons Prohibition Regime', Global Governance 13, 217 235. https://doi.org/10.1111/i.1468-2478.2006.00417.x

Knapp, A. (2005) 'The HBV and HCV Pandemic: Health, Political, and Security Challenges' Political Science Quarterly, Volume 120, Number 2. https://doi.org/10.1002/j.1538165X.2005.tb00546.x

Lancet (2008) 'Commentary, Human Security Approach for Global Health', The Lancet, vol. 372, p.13-14. doi: 10.1016/S0140-6736(08)60971-X

Lucas, A. (2002) Public Health in Nigeria, Arcbives of Ibadan Medicine, An International Journal of Medicine Science, Vol. 3, No.2, pp. 41-44.

Lynch John W., Smith George D., Kaplan George and House James S. (2000) Income Inequality and Mortality: Importance to Health of Individual Income, Psycho Social Environment, or Material Condition, BMJ; 320:1200-4. doi: https://doi.org/10.1136/bmi.320.7243.1200

Maclean, S. (2008) 'Microbes, Mad Cows and Militaries: Exploring the Links between Health and Security' Security Dialogue, vol. 39, no. 5, pp.475-494. https://doi.org/10.1177/0967010608096149.

McSweeney, Bill (1996) Identity and Security: Buzan and the Copenhagen School, Review of International Studies, 22 (1):81-93. DOI: https://doi.org/10.1017/S0260210500118467

Makeri, D.Y. (2003) 'Health Care Delivery System in Nigeria'. Occasional Publication Papers of the National Institute Interactive Sessions 2001. Kuru: National Institute and Strategic Studies, Nigeria, pp. 61-89.

Massoud, O. (2008) 'Governance and Primary Health Care Delivery in Nigeria' M. Sama and V. Nguyen (eds.) Governing Health Systems in Africa, CODESRIA: Dakar, pp.15-24.

Morikawa, M.J. (2008) 'Effect of Security Threat on Primary Care Access in Logar Province, Afghanistan', Medicine, Conflict and Survival, Vol.24, No.1, pp. 59-64. doi: 10.1080/13623690701775247

NAN (2016) Preventing Lassa Fever Infection in Nigeria. The Guardian. Available at: http://guardian.ng/news/preventing-lassa-fever-infection-in- nigeria/ accessed on $5 / 22 / 2016$.

National Bureau of Statistics (2007) Nigeria Poverty Assessment 2007, Federal Republic of Nigeria. National Centre for Diseases Control 2019 website.

National Primary Health Care Development Agency

Nigeria Demographic and Health Survey (2003), Abuja: NPC

Nigeria Demographic and Health Survey (2008), Abuja: NPC

Nwakioko J., James K., Switzer G and Stern J. (2016) 'Giving Back: A Mixed Methods Study of the Contributions of US-based Nigerian Physicians to Home Country Health Systems', Globalisation and Health, 12:33. doi: 10.1186/s12992-016-0165-9

Obiajulu, N. (2007) 'The Right to Health in Nigeria. Right to Health in the Middle East' Project, Law School, University of Aberdeen. Available at http://www.abdn.ac.uk/law/hhr.shtml (Accessed on 19 September, 2010).

OECD (2015) Africa Development Aid at a Glance 2015 Editions. Available at: https://www.oecd.org/dac/stats/documentupload/2\%20Africa $\% 20$ \%20Development $\% 20$ Aid $\% 20 a t \% 20 a \% 20$ Glance $\% 202015$.pdf. Accessed on 7/15/2016.

Ogundipe, Sola (2011) "World Bank Seeks Adoption of Ondo State's Abiye Project as Model for Africa", July 19, 2011, http://www.vanguardngr.com/2011/07/world-bank-seeksadoption-of-ondo-state $\% \mathrm{E} 2 \% 80 \% 99 \mathrm{~s}$-Abiye-project-as-model-for-africa/. Accessed on $18^{\text {th }}$ March 2013. 
Muhibbu-Din, M. O. (2020). Human security in developing regions: Critical perspectives of health security in Nigeria. Journal of Human Sciences, 17(4), 1054-1068. doi:10.14687/jhs.v17i4.5719

Olaniyan, O. And Lawanson, A. (2010) Health Expenditure and Health Status in Northern and Southern Nigeria: A Comparative Analysis Using NHA Framework. Paper Presented at the CSAE Conference held at St Catherine College, University of Oxford, Oxford, UK, March 2010. Available at: http://www.csae.ox.ac.uk/conferences/2010-EDiA/papers/451Lawanson.pdf. Accessed on 06/09/2013

Onoka CA, Onwujekwe OE, Hanson K, Uzochukwu BSC. 'Examining catastrophic health expenditures at variable thresholds using household consumption expenditure diaries'. Tropical Medicine International Health 2011; 16: 1334-41. doi: 10.1111/j.13653156.2011.02836.x.

Onwujekwe O., Hanson K., Uzochukwu B. (2012) 'Examining Inequities in Incidence of Catastrophic Health Expenditures on Different Healthcare Services and Health Facilities in Nigeria', PLoSONE 7(7), p1-6. https://doi.org/10.1371/journal.pone.0040811.

Onwujekwe O, Hanson K, Uzochukwu B, Ichoku H, Ike E, Onwughalu B. 'Are malaria treatment expenditures catastrophic to different socio-economic and geographic groups and how do they cope with payment? A study in southeast Nigeria'. Tropical Medical International Health 2010; 15: 18-25. doi: 10.1111/j.1365-3156.2009.02418.x.

PSI : Nigeria. Available at www.psi.org/nigeria. Accessed on 1/29/2014

Parmley, William W. (2000) 'Poverty and Health', Journal of American College of Cardiology, Vol. 35, No. 5, pp.1359-60.

Punch (2018) WHO Rates Nigeria Low in Health Coverage. Available at: https://www.msn.com/en-xl/africa/africa-top-stories/who-rates-nigeria-low-in-healthcoverage/ar-BBQOY7w?li=BBQbhAJ\&ocid=wispr. Accessed on 12/12/18

Roe, P. (2008) 'Value' of Positive Security', Review of International Studies, 34 (4), pp. 777-794. https://doi.org/10.1017/S0260210508008279.

Shiffman, J. and Okonofua, F.E. (2006) 'The State of Political Priority for Safe Motherhood in Nigeria', BJOG; 114:127-133. DOI: 10.1111/j.1471-0528.2006.01184.x

Soyinbo, A. (2005) Health Care Delivery under Conflict: How Prepared is West Africa? Ibadan: University Press Plc.

Stronks, K. and Mackenback, J.P. (2005) 'Evaluating the Effect of Policies and Interventions to Address Inequalities in Health: Lessons from A Dutch Programme', European Journal of Public Health, 16 (4) 346-53. https://doi.org/10.1093/eurpub/cki157

Suhrke, A. (1999) 'Human Security and the Interest of States', Security Dialogue, 30(3):265-276. https://doi.org/10.1177/0967010699030003002.

Tajbakhsh, S. (2005) The Seven Challenges of Operationalizing the Concept "Human Security: 60 Minutes to Convince" Organized by UNESCO, Section of SHS/ FPH/ PHS September 13, 2005-09-14, Paris, France, Available at http: //www.peacecenter.sciences-po.fr/ pdf/unesco (Accessed on 15 March, 2009)

Tadjbakhsh, S. and Chenoy, A. (2007) Human Security. Concepts and Implications. London: Routledge.

Tankwanchi ABS, Ozden C, Vermund SH. Physician emigration from sub-Saharan Africa to the United States: analysis of the 2011 AMA physician masterfile. PLoS Med. 2013; 10.

Thompson, T. S. (2004) Keynote Address Presented in a Conference on The Human Security Challenges of HIV/AIDS and Other Communicable Diseases: Exploring Effective Regional and Global Responses, Tokyo: JCIE, pp. 22-28.

Tien, Marie, Sylvia Ness, UgochukwuAmanyeiwe, EchenduAdinma, UzoEbenebe, and Azubike Nweje (2009) Nigeria: Reproductive Health Commodity Security Situation Analysis. Arlington, Va.: USAID | DELIVER PROJECT, Task Order 1.

The Guardian (2019) Nigeria's Low Ranking in Global Healthcare Index https://guardian.ng/opinion/nigerias-low-ranking-in-global-healthcare-...1 $16 / 2 / 2019$. 

Journal of Human Sciences, 17(4), 1054-1068. doi:10.14687/jhs.v17i4.5719

UNAIDS Nigeria http://www.unaids.org/en/regionscountries/countries/nigeria. Accessed on $\underline{18 / 02 / 19}$.

United Nations Development Programme (UNDP), 1994. Human Development Report Annual Report, New York: UNDP.

United Nations Trust Fund for Human Security (2007) The Trust Fund for Human Security for the "Human-Centred" 21 ${ }^{\text {st }}$ Century, Japan Global Issues Cooperation Division, Ministry of Foreign Affairs of Japan, pp. 1-16. Available at http: //www.mofa.go.jp/mofab/gaikohs/index.html. (Accessed on 16 March 2009).

Vanguard 2017 Communicable Diseases, Others take Deadly Toll on Nigerians- Study. https://www.vanguardngr.com/2017/09/communicable-diseases-others-take-deadly-tollnigerians-study/

Viral Hemorrhagic Fever Consortium, Lassa Fever. Available at: http://vhfc.org/lassa fever. Accessed on 5/22/2016

World Development Indicators (2015a) Available at: wdi.worldbank.org/table/2.20. Accessed on $12 / 25 / 2015$.

World Development Indicators (2015b) Available at: http://data.worldbank.org/country/nigeria. Accessed on 12/25/2015.

World Health Organization (2010) Health Systems Financing: The Path to Universal Coverage, Geneva: WHO

World Health Organization (2018a) Global Tuberculosis Report Geneva: World Health Organization.

World Health Organization (2018b) Emergencies Preparedness, Response. Lassa Fever-Nigeria. Disease Outbreak News. Available at: https://www.who.int/csr/don/20-april-2018lassa-fever-nigeria/en/. Accessed on 12/04/2018.

World Health Organization Global Health Expenditure database. Available at: https://www.indexmundi.com/facts/nigeria/indicator/SH.XPD.OOPC. Accessed on 04/12/18.

World Health Organization (2019) Nigeria. Available at: https://www.who.int/countries/nga/en/. Accessed on 16/02/19. 